\title{
Pengaruh Penyuluhan Partisipatif untuk Meningkatkan Pengetahuan Ibu tentang Penerapan Gizi Seimbang dalam Penanggulangan Stunting
}

\section{Effect of a Participatory Health Campaign on Stunting Reduction amongst Children: a Quantitative Study to Improve Mothers' Knowledge in Balanced Nutrition Practice}

\author{
Rohayati $^{1}$, Aprina ${ }^{2}$ \\ Jurusan Keperawatan Poltekkes Tanjungkarang, Indonesia
}

\section{ARTICLE INFO}

\section{Article history}

Received date

18 Aug 2021

Revised date

23 Aug 2021

Accepted date

24 Aug 2021

Keywords:

Balanced nutrition;

Counseling;

Toddlers.

\section{Kata kunci:}

Gizi seimbang;

Konseling;

Balita.

\begin{abstract}
ABSTRAK
The incidence of stunting in Lampung increased from 3 (three) to 4 (four) out of 10 (ten) toddlers who experienced stunting. One way to overcome the high incidence of stunting is through counseling about balanced nutrition. The purpose of the study was to measure the effect of participatory counseling on the application of balanced nutrition to children under five on stunting prevention. This type of quantitative research with a Quasiexperimental research design was conducted in Panjang Bandar Lampung, from April to November 2020. The subjects were 60 mothers of children under five who were divided into the intervention group (30 people), and the control group (30 people). The research instrument used was a questionnaire and a knowledge test instrument, the intervention group received treatment in the form of participatory counseling while the control group only filled out the research instrument, namely a questionnaire. The previous data analysis was tested for normality by Shapiro Wilk then tested the data using the t-test. The results showed that there was an effect of participatory counseling in the application of balanced nutrition in increasing the knowledge of mothers of children under five ( $\mathrm{p}$ value $=0,010$ ). Participatory counseling was more effective in increasing knowledge about balanced nutrition compared to the control group ( $p$-value $=0,000$ ). In conclusion, participatory counseling is significant in increasing mother's knowledge about balanced nutrition and has a better effect than other methods. Suggestion, one method of health promotion to overcome the problem of stunting is through participatory counseling.
\end{abstract}

Angka peristiwa stunting di Lampung bertambah jadi 3 (tiga) hingga 4 (empat) dari 10 (sepuluh) balita yang hadapi stunting. Salah satu metode mengatasi tingginya peristiwa stunting ialah lewat penyuluhan mengenai gizi seimbang. Tujuan penelitian untuk mengukur pengaruh penyuluhan partisipatif tentang pelaksanaan gizi seimbang pada anak balita terhadap penanggulangan stunting. Tipe penelitian kuantitatif dengan desain Quasi-ekperimen, dilaksanakan di Panjang Bandar Lampung, mulai April-Nopember 2020. Subjek yaitu 60 ibu balita dipecah jadi kelompok intervensi (30 orang), serta kelompok kontrol (30 orang). Instrumen penelitian yang digunakan merupakan kuesioner serta instrument test pengetahuan, kelompok intervensi memperoleh perlaukan berbentuk penyuluhan partisipatif sedangkan kelompok kontrol cuma berbentuk pengisian instrumen penelitian ialah kuesioner. Analisis data diuji normalitas Shapiro wilk kemudian uji informasi memakai uji $t$-test. Hasil menampilkan ada pengaruh penyuluhan secara partisipatif dalam pelaksanaan gizi seimbang dalam tingkatkan pengetahuan ibu balita ( $p$-value $=0,010)$. Penyuluhan secara partisipatif lebih efisien dalam tingkatkan pengetahuan tentang gizi seimbang dibanding dengan kelompok kontrol ( $p$ value $=0,000)$. Kesimpulan, penyuluhan secara partisipatif signifikan dalam meningkatkan pengetahuan ibu tentang gizi seimbang, dan memiliki efektifitas yang lebih baik dibanding tata cara lain. Salah satu satu tata cara promosi kesehatan untuk mengatasi permasalahan stunting ialah melalui penyuluhan secara partisipatif.

Corresponding Author:

Aprina

Jurusan Keperawatan, Politeknik Kesehatan Tanjung Karang, Indonesia

Email: aprinamurhan@yahoo.co.id 


\section{PENDAHULUAN}

Generasi yang berkembang maksimal ataupun tidak stunting mempunyai tingkatan kecerdasan yang lebih baik, dapat memberikan energi saing yang baik di bidang pembangunan serta ekonomi. Disamping itu, perkembangan maksimal bisa kurangi beban terhadap resiko penyakit degeneratif. Penyakit degeneratif semacam diabetes, hipertensi, jantung, ginjal ialah penyakit yang memerlukan bayaran penyembuhan besar. Dengan demikian, apabila perkembangan stunting bisa dicegah, maka diharapkan perkembangan ekonomi dapat lebih baik, tanpa dibebani oleh biaya-biaya penyembuhan terhadap penyakit degeneratif (Aryastami \& Tarigan, 2017).

Stunting ialah kasus gizi yang dialami dunia terutama negara-negara miskin serta berkembang. Stunting ialah permasalahan gizi kurang yang kronis, berakibat pada jangka pendek ataupun panjang, yang pada gilirannya tingkatkan penyakit serta jadi beban yang berat. Stunting pada masa balita akan mempengaruhi mutu kehidupan di masa umur sekolah, anak muda, apalagi berusia (Unicef Indonesia, 2013).

Hasil kajian Unicef Indonesia, mengatakan bahwa salah satu aspek pemicu stunting merupakan pengetahuan yang tidak mencukupi serta praktik-praktik gizi yang tidak pas (Unicef Indonesia, 2013). Pola makan sangat penting sebab erat hubungannya dengan kondisi gizi, paling utama mutu serta kuantitas santapan yang disantap. Keragaman tipe pangan yang disantap akan mempengaruhi mutu serta kelengkapan zat gizi yang bermacam-macam hingga kualitas serta kelengkapan zat gizi yang akan memenuhi kebutuhan (Kementerian Kesehatan RI, 2014). Hasil penelitian Samuel, et al. (2017), didapatkan kalau anak yang tidak stunting menunya lebih bermacam-macam dibanding anak yang stunting. Tidak hanya itu terdapat perbandingan konsumsi zat gizi makro tenaga serta protein dan konsumsi zat gizi mikro semacam vit $\mathrm{C}$, kalsium serta fosfor antara anak stunting serta tidak stunting.

Penelitian lain yang dilakukan oleh Nurbaiti, et al. (2014), tentang kerutinan makan pada anak umur 2 tahun ke atas di Lombok Tengah, bahwa sebagian besar warga membiarkan anak mereka membeli jajanan paling utama pentol (bakso cilok dibuat dari tepung kanji dicampur sedikit daging serta kombinasi bumbu) serta santapan ringan yang dijual keliling desa ataupun di warung. Anak dibiarkan memilah santapan yang disukai tanpa terdapat larangan. Tidak hanya itu, penelitian yang dilakukan oleh Yata \& Habib (2018), mengatakan kalau penyuluhan yang dilakukan kepada ibu-ibu balita menunjukkan terdapatnya kenaikan pemahaman ibu untuk lebih mencermati pemeliharaan kesehatan anaknya. Tetapi dalam penelitian ini, penyampaian pesan masih dilakukan lewat komunikasi satu arah, tanpa mencermati perspektif ibu-ibu balita, selain itu penyampaian pesan gizi serta kesehatan belum mengaitkan aspek sosial budaya wilayah setempat.

Penyuluhan gizi kepada ibu serta para penjaga balita jadi salah satu saran Unicef Indonesia (2013) mengentaskan permasalahan stunting di Indonesia. Penyuluhan gizi ialah bagian aktivitas pembelajaran kesehatan, didefinisikan selaku upaya terencana untuk mengganti sikap orang, keluarga, kelompok serta warga dalam bidang kesehatan spesialnya dalam bidang gizi (Dewi \& Aminah, 2016).

Penyuluhan dilakukan dengan memakai bermacam tata cara serta media yang disesuaikan dengan target. Penyuluhan dengan tata cara biasa semacam ceramah serta tanya jawab membuat target bosan serta kurang tertarik, sehingga tidak efisien. Ibu butuh diberikan penyuluhan yang bisa membuat mereka bahagia, bergairah dengan membuat mereka ikut serta secara aktif. Tata cara partisipatif yang diiringi dengan praktek pemilihan santapan sehat, diharapakan bisa membuat ibu lebih gampang menguasai dan mempunyai keterampilan dalam memilah santapan, termasuk santapan yang sehat untuk balitanya. Tata cara penyuluhan partisipatif dengan memberikan peluang ibu secara langsung mempraktekkan memilah santapan sehat untuk balita, dengan harapan target lebih aktif, bisa lebih baik dalam meresap modul, serta data yang diberikan.

Hasil Studi Kesehatan Dasar (Riskesdas) tahun 2018, status gizi pada balita di Indonesia masih lumayan besar. Prevalensi berat kurang (underweight) 17,7\%, terdiri dari 3,9\% gizi kurang baik serta $13,8 \%$ gizi kurang; prevalensi stunting $30,8 \%$ terdiri dari $11,5 \%$ sangat pendek serta $19,3 \%$ pendek; prevalensi wasting $10,2 \%$ terdiri dari 3,5\% sangat kurus serta $6,7 \%$ kurus (Kementerian Kesehatan RI, 2018).

Hasil Riskesdas tahun 2018, angka stunting di Lampung merupakan $30 \%$. Jadi 3 hingga 4 dari 10 balita hadapi stunting. sedangkan informasi dari Dinas Kesehatan Provinsi Lampung (2018) menginformasikan peristiwa stunting di Kota Bandar lampung tahun 2018 sebesar $15,5 \%$ dengan kecamatan yang memiliki nilai stunting besar ialah Kecamatan Panjang sebesar $46,6 \%$, tetapi terdapat pula kecamatan yang tidak memiliki permasalahan stunting semacam Kecamatan Enggal, 
Kecamatan Tanjung Karang Barat serta Kecamatan Teluk Betung Utara.

Hasil pre-survey yang dilakukan terhadap 10 balita yang hadapi stunting di Daerah Kerja Puskesmas Panjang Bandar Lampung diperoleh kalau sebanyak 4 balita (40\%) dengan tinggi ibu 150 centimeter, 3 orang (30\%) dengan sosial ekonomi rendah, 2 orang $(20 \%)$ dengan pembelajaran ibu rendah serta 1 orang (10\%) status imunisasi tidak lengkap, tidak hanya itu bersumber pada hasil wawancara kepada ibu balita dari 10 orang responden ada 8 orang $(80 \%)$ berkata kalau ibu tidak mengenali gizi berarti yang wajib diberikan kepada balitanya yang hadapi stunting, sepanjang ini pula responden berkata petugas kesehatan cuma membagikan media penyuluhan berbentuk leaflet serta tidak sepunuhnya bisa menguasai dari media tersebut.

Kebaharuan pada penelitian ini pada tata cara penyuluhannya yang menekankan pada media yang digunakan ialah penyuluhan partisifatif tentang pengaruh penyuluhan partisipatif tentang pelaksanaan gizi seimbang pada anak balita terhadap penanggulangan stunting. Penelitian ini bertujuan untuk mengenali pengaruh penyuluhan partisipatif tentang pelaksanaan gizi seimbang pada anak balita terhadap penanggulangan stunting.

\section{METODE}

Penelitian ini sudah dilakukan di Daerah kerja Puskesmas Panjang pada bulan AprilNovember 2020. Desain penelitian yang digunakan dalam penelitian ini merupakan quasi eskperimen dengan desain pre-test post-test one control group design, kelompok penyuluhan dibagi jadi 2 yaitu kelompok kontrol serta kelompok intervensi.

Target penelitian ini merupakan ibu yang memiliki balita stunting. Perhitungan ilustrasi memakai rumus perbandingan mean 2 kelompok, dengan tingkatan kesalahan 1\%, power $90 \%$, selisih bermakna 10 poin dan $10 \%$, sehingga didapatkan minimun 30 subjek untuk masingmasing kelompok. Pengambilan ilustrasi dilakukan dengan metode purposive sampling dengan kriteria inklusi: Ibu mempunyai balita yang hadapi stunting serta tidak mempunyai penyakit kronis yang lain, tidak memiliki kendala jantung, hati, tidak lagi menempuh intervensi gizi sejenis, serta bersedia ikut serta dalam penelitian ini, ibunya dapat membaca serta menulis. Informasi yang dikumpulkan berbentuk informasi ciri responden (usia, pembelajaran ibu, pekerjaan serta ASI eksklusif), pengetahuan, ibu memakai kuesioner.

Total 60 subjek yang cocok dengan kriteria inklusi serta eksklusi, setelah itu dipecah ke dalam 2 kelompok, ialah yang kelompok kontrol dengan memakai media leaflet serta kelompok intervensi dengan memakai media demonstrasi serta penyuluhan. Penelitian ini dilakukan dengan pemberian intervensi sebanyak 2 kali sepanjang 3 minggu dengan modul selaku berikut: minggu 1: Modul stunting serta pencegahannya, minggu II: Modul jatah mengkonsumsi sayur serta buah serta kerutinan makan yang baik untuk ibu serta balita, serta minggu III: Demonstrasi pemilihan sayur serta mengkonsumsi gizi yang baik untuk ibu serta balita. Pre-test dilakukan bertepatan dengan pengambilan informasi dini serta intervensi awal. Post-test kuesioner pengetahuan dilakukan sehabis intervensi akhir. Penelitian ini telah disetujui oleh Komisi Etik Penelitian Kesehatan Politeknik Kesehatan Tanjung Karang dengan Nomor. 278/ KEPK- TJK/ VII/ 2020.

Analisis univariat berbentuk penyajian frekuesi serta persentase untuk memandang ciri responden yang terdiri dari usia, pembelajaran ibu, pekerjaan serta ASI eksklusif. Analisis bivariat digunakan untuk menganalisis terdapat tidaknya pengaruh penyuluhan partisipatif dengan uji paired sample $T$ - test, sebaliknya untuk uji beda 2 kelompok memakai independend $t$-test. Bila informasi tidak wajar, dilanjutkan menggunakan analisis Mann-whitney serta Wilcoxon test. Perbandingan proporsi berpasangan diolah memakai McNemar test.

\section{HASIL}

Tabel 1. Karakteristik Responden

\begin{tabular}{llrr}
\hline \multicolumn{2}{c}{ Karakteristik Responden } & n & \% \\
\hline Usia & 20-24 Tahun & 37 & 61,7 \\
\hline Pendidikan & 25-30 Tahun & 23 & 38,3 \\
\hline & SD & 45 & 75,0 \\
\hline & SMP & 10 & 16,7 \\
\hline Pekerjaan & SMA & 5 & 8,3 \\
\hline & IRT & 50 & 83,3 \\
\hline Asi Eksklusif & Wiraswasta & 7 & 11,7 \\
\hline & Tani & 3 & 5,0 \\
\hline & Ta & 45 & 75,0 \\
\hline
\end{tabular}

Berdasarkan tabel 1 dapat dilihat bahwa usia responden yang paling muda adalah 20 tahun dan paling tua adalah 30 tahun. Karakteristik responden dari segi usia, yang paling banyak yaitu pada kelompok umur 20-24 tahun sebesar $61,7 \%$, usia $25-30$ tahun sebesar $38,3 \%$. Untuk karakteristik dari pendidikan terakhir yang paling 
banyak adalah tamat SD sebesar 75\% (45 responden). Sedangkan untuk pendidikan tamatan SMP/sederajat $16,7 \%$ (10 responden ) dan tamat SMA/Sederajat $8,3 \%$ (5 orang). Pekerjaan responden terbanyak merupakan IRT sebanyak $83,3 \%$ (50 responden), wiraswasta $11,7 \%$ (7 reponden) dan Tani 5\% (3 responden). ASI eksklusif terbanyak yaitu ibu dengan menyusui ASI eksklusif sebanyak 75\% (45 reponden) dan tidak menyusi ASI eksklusif sebanyak 25\% (15 responden).

Tabel 2. Pengetahuan Ibu

\begin{tabular}{|c|c|c|c|c|c|c|}
\hline \multicolumn{2}{|c|}{ Kelompok } & \multirow{2}{*}{$\frac{\mathbf{n}}{30}$} & \multirow{2}{*}{$\begin{array}{r}\text { Mean } \\
42,83\end{array}$} & \multirow{2}{*}{$\begin{array}{c}\text { SD } \\
12,70\end{array}$} & \multirow{2}{*}{$\begin{array}{r}\text { Min } \\
20\end{array}$} & \multirow{2}{*}{$\begin{array}{r}\text { Maks } \\
65\end{array}$} \\
\hline Intervensi & Pre-test & & & & & \\
\hline & & 30 & & 11,07 & 35 & \\
\hline & & 30 & 35 & 8,808 & 20 & 50 \\
\hline & Post-test & 30 & 34,50 & 8,444 & 20 & 50 \\
\hline
\end{tabular}

Berdasarkan tabel 2, pengetahuan ibu sebelum dilakukan penyuluhan pada kelompok intervensi diperoleh hasil rata-rata 42,83, standar devisiasi 12,70 nilai minimum 20 dan nilai maksimal 65, dan pengetahuan ibu setelah dilakukan penyuluhan partisipatif diperoleh hasil rata-rata 59,17, standar devisiasi 11,07 dengan nilai minimum 35 dan maksimal 75 .

Sementara pada pengetahuan ibu pada kelompok kontrol diperoleh hasil pre-test ratarata 35,00 dengan standar deviasi 8,808 nilai minumim 20 dan maksimal 50, serta diperoleh hasil post-test dengan rata-rata 34,50 dengan standar devisiasi 8,444 nilai minimum 20 dan nilai maksimal 50.

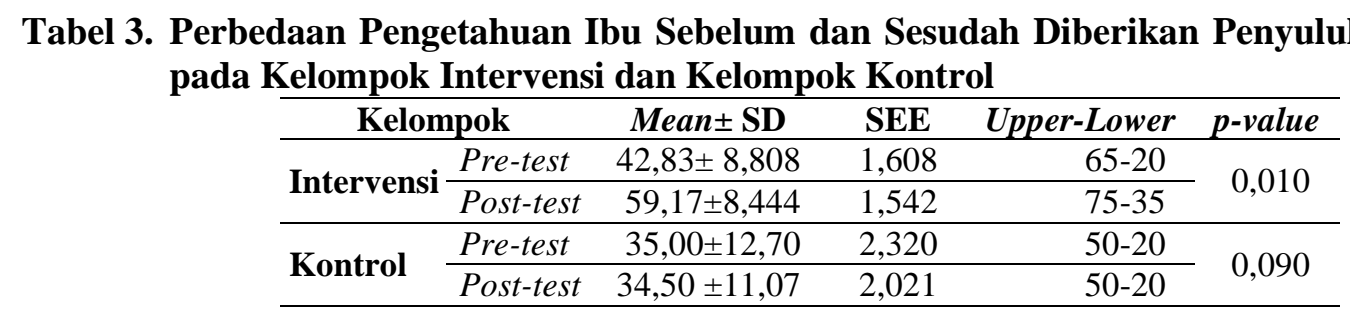

Berdasarkan tabel 3, rata-rata pengetahuan responden pada kelompok intervensi sebelum diberikan penyuluhan adalah 42,83 dan sesudah diberikan penyuluhan 59,17 , sedangkan rata rata pengetahuan kelompok kontrol pre-test 35,00 Dan post-test 34,50. Hasil uji statistik dengan menggunakan paired t-test didapatkan nilai $p$ value $=0,010$ pada kelompok intervensi sedangkan pada nilai $p$-value $=0,090$ pada kelompok kontrok sehingga dapat disimpulkan ada perbedaan pengetahuan pada kelompok intervensi sebelum dan setelah penyuluhan partisipatif pada ibu tentang penerapan gizi balita terhadap penanggulangan stunting, dan tidak ada perbedaan pengetahuan pada kelompok kontrol.

Tabel 4. Pengaruh Penyuluhan Partisipatif terhadap Penanggulangan Stunting pada Ibu

\begin{tabular}{lcccr}
\hline Kelompok & $\begin{array}{c}\text { Mean } \\
\pm \text { SD }\end{array}$ & SEE & $\begin{array}{c}\text { Upper- } \\
\text { Lower }\end{array}$ & p-value \\
\hline \multirow{2}{*}{ Intervensi } & 59,17 & 2,021 & 19,578 & 0,000 \\
& $\pm 11,07$ & & & \\
Kontrol & 34,50 & 1,542 & 19,571 & \\
\hline
\end{tabular}

Pada tabel 4 menunjukan bahwa pengetahuan ibu pada kelompok intervensi dan kelompok kontrol didapatkan nilai p-value $0,000<0,005$ artinya ada pengaruh penyuluhan partisipatif terhadap penanggulangan stunting.

\section{PEMBAHASAN}

\section{Pengetahuan Ibu}

Tingkatan pengetahuan gizi seorang mempengaruhi terhadap perilaku serta sikap dalam memilah santapan yang memastikan mudah tidaknya seorang menguasai khasiat isi gizi dari santapan yang disantap. Pengetahuan gizi yang baik diharapkan mempengaruhi konsumsi santapan yang baik, sehingga bisa mengarah ke status gizi yang baik pula. Pengetahuan gizi memiliki peranan sangat berarti dalam pembuatan makan rutin seorang. Sehingga penyuluhan kesehatan yang diberikan bisa mempengaruhi sikap ibu tentang gizi seimbang balita jadi lebih baik. Pembelajaran ibu ataupun orang tua diharapkan dapat mengasuh anak stunting lebih baik. Hal ini didukung oleh Yudesti (2012) serta Ernawati (2006) yang melaporkan jika semakin besar tingkatan pembelajaran resmi orang tua maka semakin besar keahlian mereka untuk memahami data dengan wawasannya tentang autis sehingga dalam penanganannya menjadi lebih baik.

Tingkatan pembelajaran bisa pengaruhi anggapan seorang untuk lebih menerima ide-ide serta teknologi baru. Pembelajaran ialah salah satu aspek yang mempengaruhi anggapan seorang. Sebab bisa membuat seorang lebih mudah mengambil keputusan serta berperan 
(Sari, 2010). Tingkatan pembelajaran yang lebih besar dapat mempermudah seorang untuk memahami data serta mengimplementasikannya dalam kehidupan sehari-hari (Rusimah, 2011).

Hasil penelitian Rozali (2016) menampilkan terdapatnya hubungan tingkatan pembelajaran ibu terhadap pengetahuan, aksi serta pola pikir dalam mencari serta mendapatkan bermacam data pengetahuan tentang gizi balita. Begitu pula dengan hasil penelitian Trimanto (2008) meyakinkan kalau semakin besar pembelajaran orangtua maka semakin besar kepedulian terhadap kesehatan, terutama dalam hal melindungi status gizi anak.

Tidak hanya itu terdapat hal lain yang mempengaruhi pengetahuan antara lain pekerjaan. Tipe pekerjaan yang dilakoni umumnya mencerminkan tingkatan status ekonomi. Keluarga dengan status ekonomi menengah ke bawah, membolehkan mengkonsumsi pangan dengan gizi rendah sehingga mempangaruhi status gizi anak (Supariasa, et al., 2012).

Pemberian ASI eksklusif memiliki bermacam khasiat untuk ibu serta bayi dimana ASI ialah santapan alamiah yang baik untuk bayi dan balita, instan, murah, gampang dicerna, mempunyai komposisi zat gizi yang sempurna cocok dengan kebutuhan serta keahlian pencernaan bayi dan balita. ASI menunjang tumbuh kembang bayi dan balita sebab kalsium ASI lebih efektif diserap dibandingkan susu pengganti ASI (Prasetyono, 2009).

Keberhasilan ASI secara eksklusif bisa dipengaruhi oleh aspek seperti status pekerjaan. Ibu yang tidak bekerja mempunyai banyak waktu untuk menjaga bayinya dan memberikan ASI eksklusif. Hasil penelitian menampilkan bahwa dari 130 ibu terdapat 84 responden IRT yang memberikan ASI secara ekskusif. Hal ini sesuai dengan hasil penelitian oleh Okawary \& Sugiyanto (2015) yaitu 51,9\% ibu yang tidak bekerja memberikan ASI eksklusif, dan ada hubungan yang signifikan antara status pekerjaan ibu dengan pemberian ASI eksklusif di daerah kerja Puskesmas Seyegan Sleman Yogyakarta.

Bagi peneliti pengetahuan tidak cuma didapatkan dari tingkatan pembelajaran besar namun bisa diperoleh dari pengalaman serta data yang diperoleh warga.

\section{Perbedaan Pengetahuan Ibu Sebelum dan Sesudah pada Kelompok Intervensi dan Kelompok Kontrol}

Ada perbedaan pengetahuan pada kelompok intervensi sebelum dan setelah penyuluhan partisipatif pada ibu tentang penerapan gizi balita terhadap penanggulangan stunting, dan tidak ada perbedaan pengetahuan pada kelompok kontrol.

Rendahnya pengetahuan ibu balita menimpa gizi balitanya disebabkan minimnya pengetahuan ibu balita tersebut. Minimnya data yang setelah itu jadi latarbelakang minimnya pengetahuan serta rendahnya perilaku ibu balita tersebut. Ibu balita cenderung tidak mencermati kebutuhan gizi anak sesuai umurnya.

Data gizi kurang pada balita tidak cocok dengan pertumbuhan era di kala ini. Di kala ini merupakan masa globalisasi dimana akses mencari data kesehatan spesialnya gizi balita sangat gampang ditemui. Perihal tersebut sebab teknologi penyedia data kesehatan dikala ini semakin mutakhir. Pergantian perilaku pada ibu balita dikira dipengaruhi oleh seberapa jauh isi pesan ataupun rangsangan dari penyuluhan kesehatan dicermati, diterima serta dimengerti dengan baik oleh ibu (Effendi, 2009).

Pengetahuan merupakan komponen pembuatan perilaku serta sikap dari seorang. Sehingga apabila pengetahuan dari ibu balita tidak mencukupi berakibat pada gizi balita. Selain itu akan berakibat pada perilaku serta sikap dari ibu balita dalam perihal pemenuhan gizi balitanya. Perihal tersebutlah yang menimbulkan angka balita yang memiliki gizi kurang masih banyak bahkan cenderung bertambah.

Santapan balita wajib penuhi standar kecukupan gizi balita. Gizi seimbang ialah keadaan yang menjamin badan mendapatkan santapan yang cukup baik serta memiliki seluruh zat gizi. Dengan gizi seimbang, balita akan memiliki energi dan ketehanan tubuh yang maksimal sehingga tidak gampang sakit (Sulistyoningsih, 2011).

Bagi peneliti pengetahuan ibu balita tentang gizi seimbang memberikan manfaat yang baik apalagi bila diperbaharui dan diteruskan. Upaya penanggulangan stunting serta perbandingan pengetahuan pada kelompok kontrol dan intervensi memberikan cerminan bahwa pentingnya peningkatan pengetahuan ibu balita melalui penyuluhan partisipatif.

\section{Pengaruh Penyuluhan Partisipatif terhadap Penanggulangan Stunting}

Tabel 4 menunjukan bahwa ada pengaruh penyuluhan partisipatif terhadap penanggulangan stunting. Pengetahuan ibu balita yang bertambah antara lain mengetahui jenis-jenis gizi yang diperlukan oleh balita, makanan-makanan apa 
saja yang diperlukan balita untuk penuhi gizi seimbangnya, akibat dari kekurangan gizi, metode mengolah menu yang pas untuk balita, serta kebutuhan pemenuhan zat gizi yang seimbang untuk balita.

Saat sebelum penyuluhan kesehatan, ibu balita tidak mengenali kebutuhan gizi anak bersumber pada umurnya, zat gizi apa saja yang diperlukan untuk perkembangan serta pertumbuhan balita, pola makan balita meliputi tipe bahan santapan, frekuensi makan, jumlah santapan, serta sebagainya. Tetapi setelah diberikan penyuluhan, ibu mengenali hal-hal tersebut.

Adanya pengetahuan serta perilaku yang baik ibu terhadap gizi balita, maka ibu balita tersebut berupaya dengan optimal untuk mencukupinya. Apabila ada bermacam permasalahan di luar dari pengetahuannya misal sebab rendahnya ekonomi keluarga, ibu dengan pengetahuan yang baik akan mencari alternatif pemecahan untuk menanggulangi permasalahan tersebut. Contohnya ibu akan menanam bahan pangan dengan menggunakan pekarangan rumahnya. Dengan begitu penyuluhan kesehatan tidak cuma terpaku pada permasalahan kesehatan tersebut. Tetapi pula pada hal-hal yang mungkin bisa membatasi proses pemenuhan gizi balita tersebut.

Santapan balita wajib penuhi standar kecukupan gizi balita. Santapan sehat ada pada makanan pokok, sayur, lauk, serta buah. Makanan pokok ialah makanan yang memiliki banyak karbohidrat ataupun tepung semacam nasi, singkong, sagu, serta jagung.

Menurut Mutiara (2016) jika penyuluhan kesehatan dengan media lembar balik bisa menimbulkan pergantian pada pengetahuan serta perilaku responden. Penelitian yang dilakukan di Kota Padang ini mengatakan kalau terdapat kenaikan pengetahuan sebesar $43 \%$ serta kenaikan perilaku sebesar 9,5\%. Sehingga disimpulkan kalau pemakaian media lembar balik dalam penyuluhan kesehatan pada penelitian tersebut merupakan sangat efektif

Bagi peneliti santapan sehat ialah santapan yang memiliki zat- zat yang diperlukan oleh tubuh. Penyuluhan partisipatif dengan membagikan data kepada ibu balita serta mendemonstrasikan tentang santapan yang sehat sangat dibutuhkan supaya balita berkembang bisa beraktifitas dengan wajar. Ibu balita juga bisa melindungi kebersihan makan sehingga santapan tersebut masuk dalam ketentuan santapan sehat. Hal ini bisa menolong ibu balita dalam mengenali santapan sehat sehingga bisa menolong dalam mengatasi peristiwa stunting pada balita.

\section{SIMPULAN}

Ada perbedaan pengetahuan ibu balita pada kelompok kontrol dan kelompok intervensi. Tidak ada perbedaan pengetahuan pada kelompok kontrol, serta ada pengaruh penyuluhan partisipatif terhadap penanggulangan stunting.

Disarankan pemberian pelatihan dan pembekalan kepada petugas kesehatan agar memiliki kredibilitas dan kompetensi untuk memberikan penyuluhan partisipatif dalam penanggulangan stunting dan masyarakat agar segera merubah kebiasaan dan meningkatkan pengetahuan ibu balita dalam memberikan gizi pada bayi bahkan balita, sehingga penanggulangan stunting dapat teratasi.

\section{DAFTAR PUSTAKA}

Aryastami NK, Tarigan I. (2017). Kajian Kebijakan Penanggulangan Masalah Gizi Stunting di Indonesia. Badan Litbang Kementerian Kesehatan RI.

Dewi, M., \& Aminah, M. (2016). Pengaruh edukasi gizi terhadap feeding practice ibu balita stunting usia 6-24 bulan (the effect of nutritional knowledge on feeding practice of mothers having stunting toddler aged 6-24 months). Indonesian Journal of Human Nutrition, 3(1), 1-8.

Dinas Kesehatan Provinsi Lampun. (2018). Profil Dinkes Provinsi Lampung 2018. Bandar Lampung.

Effendi, Muh. Arief. (2009). The Power Of Corporate Governance: Teori dan. Implementasi. Jakarta: Salemba Empat.

Ernawati A. (2006). Hubungan faktor sosial ekonomi, higiene sanitasi lingkungan, tingkat konsumsi, dan infeksi dengan status gizi anak usia 2-5 tahun di Kabupaten Semarang tahun 2003. [Tesis]. Semarang: Program Pasca Sarjana Magister Gizi Masyarakat Universitas Diponegoro.

Kementerian Kesehatan RI. (2014). Angka Kecukupan Gizi yang Dianjurkan Bagi Bangsa Indonesia. Direktorat Jenderal 
Bina Gizi dan Kesehatan Ibu dan Anak. Jakarta: Kemenkes RI.

Kementerian Kesehatan RI. (2018). Laporan Hasil Riset Kesehatan Dasar (RISKESDAS). Badan Penelitian dan Pengembangan Kesehatan. Jakarta: Kemenkes RI.

Mutiara R. (2016). Pengaruh Konseling Gizi dengan Media Lembar Balik terhadap Perubahan Pengetahuan, Sikap dan Praktik Gizi Seimbang pada Wanita Usia Subur Pranikah di KUA Wilayah Kota Padang. [Skripsi]. Padang: Fakultas Kesehatan Masyarakat, Universitas Andalas.

Nurbaiti L, et al. (2014). Kebiasaan makan balita stunting pada masyarakat Suku Sasak: Tinjauan 1000 hari pertama kehidupan (HPK). Jurnal Masyarakat, Kebudayaan dan Politik, (27)2, 104-112.

Okawary, O., \& Sugiyanto, S. (2015). Hubungan Status Pekerjaan Ibu dengan Pemberian Asi Eksklusif di Wilayah Kerja Puskesmas Sayegan Sleman Yogyakarta (Doctoral dissertation, STIKES'Aisyiyah Yogyakarta).

Prasetyono, D.S. (2009). ASI Eksklusif Pengenalan, Praktik, dan Kemanfaatannya. Yogyakarta: Diva Press.

Rozali, Nur Azikin. (2016). Peranan Pendidikan, Pekerjaan Ibu Dan Pendapatan Keluarga Terhadap Status Gizi Balita Di Posyandu Rw 24 Dan 08 Wilayah Kerja Puskesmas Nusukan Kota Surakarta. [Skripsi]. Surakarta: Universitas Muhammadiyah Surakarta.

Rusimah. (2011). Hubungan Tingkat Pendidikan dan Pengetahuan Gizi dengan Kepatuhan
Diet pada Penderita Diebetes Melitus (Diabetisi) di Ruang rawat Inap RSUD Dr. H. Moch Ansari Saleh Banjarmasin Tahun 2010. [Skripsi]. Banjarbaru: Program Studi S1 Gizi, Sekolah Tinggi Ilmu Kesehatan Husada Borneo Banjarbaru.

Samuel, S., Subagio, H. W., \& Suhartono, S. (2017). Perbedaan Pola Konsumsi Dan Asupan Zat Gizi Anak Stunting Dan Tidak Stunting Usia 12-23 Bulan. Media Informasi, 13(1), 67-72.

Sari, P. (2010). Coping Stress pada Remaja Korban Bullying di Sekolah "X". Jurnal Psikologi, 8(2), 75-81.

Sulistyoningsih, Hariyani. (2011). Gizi Untuk Kesehatan Ibu dan Anak. Yogyakarta: Graha Ilmu.

Supariasa, I.D.N., Bakri, B., \& Fajar, I. (2012). Penilaian Status Gizi. Jakarta: EGC

Trimanto, A., (2008). Hubungan Antara Tingkat Pendidikan Ibu, Pendapatan Keluarga, dan Modal Sosial dengan Status Gizi Anak Balita di Kabupaten Sragen. [Tesis]. Surakarta: Universitas Sebelas Maret.

Unicef Indonesia. (2013). Ringkasan Kajian Gizi Ibu dan Anak. www.unicef.org

Yata, J. S., \& Habib, K. (2018). Nutrition education and training interventions for mothers in addressing malnutrition among children in Malakal county/South Sudan. Ahfad Journal, 35(1).

Yudesti, I., \& Prayitno, N. (2012). Perbedaan status gizi anak SD kelas IV dan V Di SD Unggulan (06 Pagi Makasar) dan SD Non Unggulan (09 Pagi Pinang Ranti) Kecamatan Makasar Jakarta Timur Tahun 2012. Jurnal Ilmiah Kesehatan, 5(1), 1-5. 